Limnol. Rev. (2015) 15, 3: 85-93

\title{
History of the development of Eemian Interglacial lakes on the basis of Cladocera subfossil analysis (Central and Eastern Poland)
}

\author{
Monika Niska \\ Department of Geoecology and Geoinformation, Institute of Geography and Regional Studies, Pomeranian University in Słupsk, \\ Partyzantów 27, 76-200 Słupsk, Poland, e-mail: monikaniska@wp.pl
}

\begin{abstract}
This paper presents the results of Cladocera subfossil analysis using material obtained from five paleolakes of the Eemian Interglacial located in central and north-eastern Poland. Analyses of Cladocera subfossils in Poland and other parts of the world have revealed detailed results covering the last 13,000 years. Cladocera subfossils from sediments older than the last glaciation have been analysed occasionally. The first analyses of older sediments were conducted in Denmark by Frey in 1962. In Poland, the first analyses of this type were conducted on material obtained in Konin. The Eemian lakes subject to the study were formed at the end of the Warta Glaciation in tunnel and kettle holes. A continuous record of environmental changes throughout the Eemian Interglacial until the early Vistulian Glaciation has been preserved in lake sediments. The bottom part of the profile consists of sands and silts, followed by gyttja and peat. The upper part of the profile contains peat and organic shales. Cladocera subfossils found in Eemian sediments were thinner and their structure was more damaged. The low degree of subfossil preservation forced a change in the method of preparation of subfossils for microscopic analysis as required by IGCP Project 158. Cladocera species determined within the studied paleolakes correspond to the present-day species inhabiting the area of Poland and Europe. The species composition and the variability in the frequency of Cladocera specimens made it possible to distinguish discrete phases of lake development associated with changes in temperature and water level, trophic state and the presence of macrophytes. The results of Cladocera analysis are well correlated with data obtained in pollen analyses.
\end{abstract}

Key words: Paleolimnology, Cladocera analysis, Eemian Interglacial

\section{Introduction}

Cladocera (water fleas) are small crustaceans that constitute lacustrine zooplankton along with Copepoda and Rotifera species. The high suitability of Cladocera species for the purposes of limnological as well as paleolimnological studies is due to their widespread occurrence, quick reactions to ecological changes and chitinous shells being preserved within lake sediments (Szeroczyńska 1985).

Cladocera subfossils have been studied at different research centres worldwide for nearly 90 years. In Poland, the analysis of Cladocera subfossils allowed researchers to reconstruct the development of lakes over the last 13,000 years starting from the deglaciation of the Vistulian Glacier (Alhonen 1986; Hofman 2000; Sarmaja-Korjonen 2002). The results of Cladoc- era analyses are used in the determination of trophic states, water level and $\mathrm{pH}$ fluctuations as well as reservoir temperatures. These factors are influenced by climate changes that may be indirectly reconstructed by means of Cladocera subfossil analysis (Nevalainen et al. 2013). Due to the high usefulness of the analysis of Cladocera subfossil content within the sediments in the reconstruction of environmental conditions, much interest has been shown in the possible use of this method for examination of sediments from before the last glaciation.

The Eemian Interglacial should be correlated with the last interglacial warming and global elevation of the sea level as determined by the analysis of oxygen isotopes within deep-sea cores, occurring between 128,000 and 118,000 years BP (Shackleton and Opdyke 1973). The climate of the Eemian Intergla- 
cial was similar to that of the Holocene. It was stable, with temperatures at its optimum point dating back to 125,000 years BP being higher than those being recorded on Earth at present (Kaspar et al. 2005). The warmer climate zones reached further north and the temperature and humidity of winter seasons was higher than that in the Holocene (van Kolfschoten 2000). The lay of the land over the area of today's Poland within the Eemian Interglacial was similar to that of the Holocene. Also similar was the diversity of deposition environments. The stratigraphy of the interglacial period has been best preserved within the lacustrine and oxbow lake sediments as well as in loess sediments with fossil soils (Lindner 1992). These sediments are the most abundant source of information on the changes in environmental conditions.

During the present interglacial period (Holocene), the increasing anthropogenic impact on the environment disturbs natural processes occurring within the ecosystems. Reconstruction of past climate changes not disturbed by human activity is very important as it allows scientists to elucidate the course of natural environmental processes and thus to estimate the impact of anthropogenic factors (Cheddadi et al. 1998).

The goal of this study was to present and compare the development of Eemian Interglacial lakes within central and eastern Poland as determined on the basis of the changes in Cladocera subfossil composition in selected paleolakes formed after the retreat of the Warta Glaciation and developed throughout the Eemian Interglacial subject to natural evolutionary processes.

\section{History of the analyses of Cladocera subfossils from the Eemian Interglacial period}

The literature on the succession of Cladocera species within the Eemian Interglacial period is sparse as few sites have been examined worldwide to date in terms of Cladocera subfossil content, often as part of pilot studies only. Remains and resting eggs of Cladocera species were occasionally found in specimens older than the last glaciation (Jessen and Milthers 1928; Cockerell 1922; MacGinitie 1949, 1953; Dickinson 1959; Erni et al. 1943; and others). In Europe, the first analysis of lacustrine Cladocera subfossils of the Eemian Interglacial period was conducted in Denmark (Frey 1962). Examinations of Eemian sediments were also conducted by researchers from Japan (Tsukada 1972; Kadota 1975) and Canada (Hann and
Karrow 1984, 1993). In Poland, the first attempts at analyses of older deposits were conducted for Eemian Interglacial deposits at Konin by Szeroczyńska (Tobolski 1991) and Pawłowski (2002). A total of 14 profiles of lacustrine sediments from the territory of Poland have been examined for the presence of Cladocera subfossils since 2000 .

\section{Study area}

The studied reservoirs, fully developed during the Eemian Interglacial, were formed at the end of the Warta Glaciation or in the early Eemian Interglacial period. Terrain troughs, including tunnel and kettle holes, were left after the retreat of the glacier and filled by accumulating water. Eemian paleolakes are discovered mainly on the occasion of the preparation of geological maps. The studied sites are located in various parts of Poland (Fig. 1), including Kuców IIc - a nonexistent reservoir within the Bełchatów open-cast mine (Balwierz 1998; Niska 2008); Besiekierz - $30 \mathrm{~km}$ north of Łódź (Janczyk-Kopikowa 1991; MirosławGrabowska and Niska 2005); Kubłowo-Kłodawa Upland (Roman and Balwierz 2010; Niska and Roman 2014); Studzieniec - north of Sierpc (Krupiński 2005; Mirosław-Grabowska and Niska 2007) in central Poland; as well as Solniki-Białystok Upland (Kupryjano-

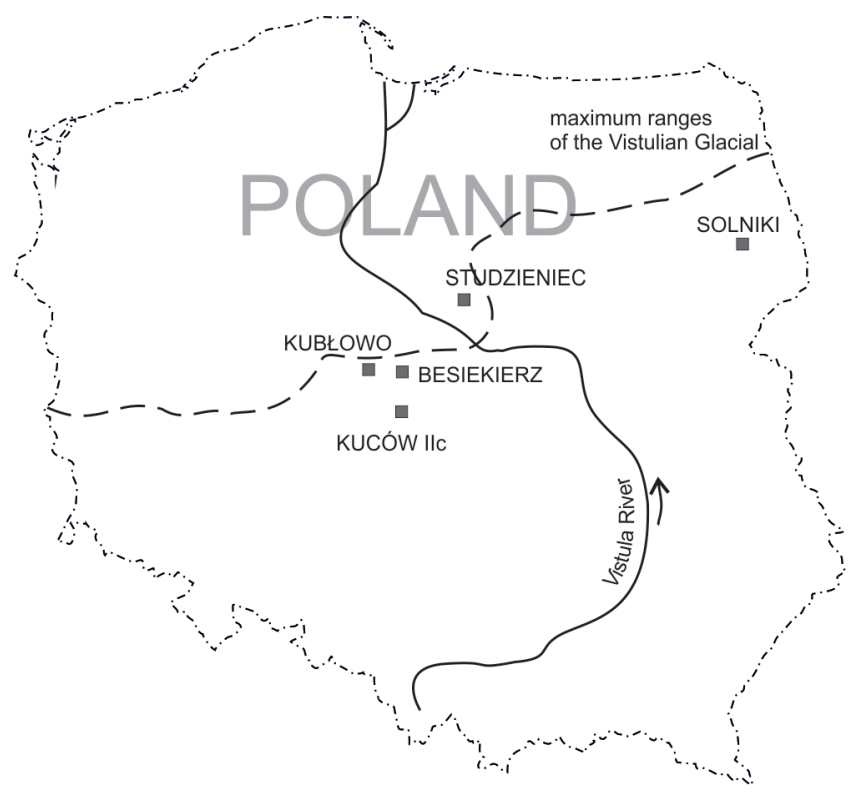

Fig. 1. Location of Eemial interglacial profiles subject to palynological analysis and Cladocera subfossil analysis: Besiekierz (Janczyk-Kopikowa 1991), Solniki (Kupryjanowicz 2008), Kuców IIc (Balwierz 1998), Studzieniec (Krupiński 2005), Kubłowo (Roman and Balwierz 2010) 
wicz 2008; Niska 2008) in eastern Poland. At the initial stages of lake developments, sediments within the lake basins consisted mainly of sands and silts, with the exception of the Solniki reservoir, which was formed relatively late and where peats were the predominant component. The full lake development periods were associated with sedimentation of gyttja and organic silts followed by peat and organic shales. Peat was predominant at the latest stages of lake history. The selected Eemian reservoirs provide a record of plant succession typical for the Eemian Interglacial, facilitating correlation of local pollen assemblage zones (L PAZ) with regional pollen assemblage zones (R PAZ) as determined by Mamakowa (1989). Chronostratigraphy of the studied sediment profiles was based on the results of palynological analyses.

\section{Methods}

Samples for Cladocera analysis were prepared according to the standard IGCP project 158 procedure (Frey 1986) modified for the purpose of the analysis of older sediments. Volumetric samples $\left(1 \mathrm{~cm}^{3}\right)$ of soft, poorly bound sediments or mass samples $(1.5 \mathrm{~g})$ of strongly diagenetic sediments were collected (one technique was used for sampling entire profiles). In order to protect the Cladocera remains from being destroyed, the samples were prepared at the temperature of $60^{\circ} \mathrm{C}$, i.e. lower than the standard temperature of $70-80^{\circ} \mathrm{C}$ (Korhola and Rautio 2001); in addition, magnetic stirring time was shortened to 20 minutes and the stirrer rate was also reduced. Microscopic analysis (magnification of $10 \times, 20 \times, 40 \times$ ) involved the counting of all Cladocera subfossils in 3-7 specimens while trying to keep the number of subfossils at no fewer than 200. The subfossils were stained with safranin $\mathrm{T}$. Identification and ecological interpretation of Cladocera species was based on the studies by Flösner (1972, 2000), Frey (1962), Goulden (1964), Hofmann (1986), Korhola (1990), Szeroczyńska (1985), and Szeroczyńska and Sarmaja-Korjonen 2007).

\section{Results and discussion}

Characterization of preservation status and species composition of Cladocera subfossils

Cladocera subfossils deposited during the Eemian Interglacial period are thinner and of more damaged structures than those originating from
Holocene deposits, and thus pose exceptional difficulties in qualitative and quantitative analyses (Niska 2008; 2012). In evolutionary terms, water flea species have not changed for hundreds of thousands of years; it is therefore assumed that the knowledge of ecological and climate requirements of present-day Cladocera can be used in the interpretation of changes occurring in lacustrine reservoirs in the past. Changes in Cladocera groups occurring within the studied lakes as the result of climate changes during the Eemian Interglacial correspond to present-day geographical distribution of species in Poland and Europe (Frey 1962; Niska 2012). Differences in species composition are due to differences in the types of studied lakes. The determined subfossils were not essentially different in size and appearance from those found within the present-day lakes, the only difference consisting in smaller thickness of chitinous shells leading to poorer coloration of subfossils.

The predominant, and the most diverse, group of species occurring within Eemian Interglacial lakes was the group of littoral forms of the Chydoridae family (Table 1 ). The species of this family are the most interesting research material as they provide information on both the lakeside zone status and the climate. Representatives of this family are the best indicators of temperature and environmental factors (Frey 1958; Goulden 1964; Poulsen 1928). The Bosminidae family was represented by the species of Bosmina longirostris, Bosmina longispina, Bosmina coregoni while the Daphnidae family was represented by Ceriodaphnia sp., the Daphnia pulex group and the Daphnia longispina group. These families inhabit mostly open water zones constituting an element of the pelagic environment (Lampert and Sommer 2001). The Sididae family was represented by one species, i.e. Sida cristallina.

The composition of the dominant Cladocera species within the sediment layers correlated with palynological levels depended on the lake age and development stage, rate of changes occurring within the lake as well as morphometric parameters of the lake (Table 1). The depth of the reservoir had a significant impact on the sedimentation rate and sediment record of zooplankton reactions to climate changes.

During the lifespan of Eemian Interglacial lakes, the dominant species included the following: Acroperus harpae, Alona affinis, Alona guttata, Alona quadrangularis, Alonella nana, Bosmina longirostris, Bosmina longispina, Camptocercus rectirostris, Chydorus sphaericus, Eurycercus lamellatus, Graptoleberis testu- 
Table 1. List of predominant Cladocera species identified within individual paleolakes (stratigraphy adapted from Mamakowa 1989)

\begin{tabular}{|c|c|c|c|c|c|c|}
\hline \multicolumn{2}{|c|}{ Stratigraphy } & $\begin{array}{c}\text { Besiekierz } \\
\text { (Niska 2008) }\end{array}$ & $\begin{array}{c}\text { Kuców } \\
\text { (Niska 2008) }\end{array}$ & $\begin{array}{c}\text { Kubłowo } \\
\text { (Niska 2014) }\end{array}$ & $\begin{array}{l}\text { Studzieniec } \\
\text { (Niska 2008) }\end{array}$ & $\begin{array}{c}\text { Solniki } \\
\text { (Niska 2008) }\end{array}$ \\
\hline 竞 & EV1 & - & - & $\begin{array}{l}\text { Chydorus sphaericus } \\
\text { Alona guttata } \\
\text { Bosmina longispina }\end{array}$ & $\begin{array}{l}\text { Chydorus sphaericus } \\
\text { Pleuroxus uncinatus } \\
\text { Bosmina longirostris }\end{array}$ & $\begin{array}{l}\text { Chydorus sphaericus } \\
\text { Alona affinis }\end{array}$ \\
\hline \multirow{7}{*}{ 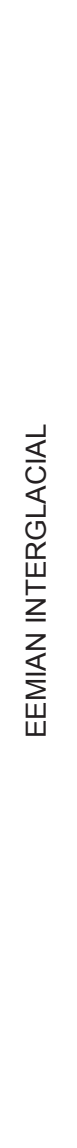 } & E7 & - & $\begin{array}{l}\text { Alona guttata } \\
\text { Bosmina longirostris } \\
\text { Alonella nana }\end{array}$ & $\begin{array}{l}\text { Bosmina longispina } \\
\text { Bosmina longirostris } \\
\text { Alona affinis } \\
\text { Acroperus harpae }\end{array}$ & $\begin{array}{l}\text { Chydorus sphaericus } \\
\text { Alona quadrangularis } \\
\text { Alona guttata } \\
\text { Bosmina longirostris }\end{array}$ & $\begin{array}{l}\text { Alona affinis } \\
\text { Camptocercus } \\
\text { rectirostris }\end{array}$ \\
\hline & E6 & - & $\begin{array}{l}\text { Graptoleberis } \\
\text { testudinaria } \\
\text { Camptocercus } \\
\text { rectirostris } \\
\text { Acroperus harpae }\end{array}$ & $\begin{array}{l}\text { Bosmina longispina } \\
\text { Bosmina longirostris } \\
\text { Alona affinis } \\
\text { Monispilus dispar }\end{array}$ & $\begin{array}{l}\text { Alonella nana } \\
\text { Alona guttata } \\
\text { Alona affinis } \\
\text { Eurycercus lamellatus }\end{array}$ & $\begin{array}{l}\text { Alona affinis } \\
\text { Camptocercus } \\
\text { rectirostris } \\
\text { Alona rectagula }\end{array}$ \\
\hline & E5 & - & $\begin{array}{l}\text { Camptocercus } \\
\text { rectirostris } \\
\text { Alona guttata } \\
\text { Alona affinis }\end{array}$ & $\begin{array}{l}\text { Alona guttata } \\
\text { Alona affinis } \\
\text { Bosmina longispina } \\
\text { Camptocercus rec. }\end{array}$ & $\begin{array}{l}\text { Acroperus harpae } \\
\text { Alona guttata } \\
\text { Bosmina longirostris } \\
\text { Eurycercus lamellatus }\end{array}$ & $\begin{array}{l}\text { Alona rectagula } \\
\text { Pleuroxus trigonellus }\end{array}$ \\
\hline & E4 & - & Eurycercus lamellatus & $\begin{array}{l}\text { Alona affinis } \\
\text { Bosmina longispina }\end{array}$ & $\begin{array}{l}\text { Alona guttata } \\
\text { Alonella nana } \\
\text { Bosmina longirostris }\end{array}$ & $\begin{array}{l}\text { Alona affinis } \\
\text { Camptocercus } \\
\text { rectirostris } \\
\text { Acroperus harpae }\end{array}$ \\
\hline & E3 & $\begin{array}{l}\text { Chydorus sphaericus } \\
\text { Camptocercus } \\
\text { rectirostris }\end{array}$ & Alona affinis & $\begin{array}{l}\text { Alona affinis } \\
\text { Bosmina longispina } \\
\text { Acroperus harpae } \\
\text { Chydorus sphaericus } \\
\text { Eurycercus lamellatus }\end{array}$ & $\begin{array}{l}\text { Alona guttata } \\
\text { Alonella nana } \\
\text { Bosmina longirostris }\end{array}$ & $\begin{array}{l}\text { Acroperus harpae } \\
\text { Chydorus sphaericus } \\
\text { Eurycercus lamellatus }\end{array}$ \\
\hline & E2 & $\begin{array}{l}\text { Camptocercus } \\
\text { rectirostris } \\
\text { Alona affinis } \\
\text { Sida cristallina }\end{array}$ & $\begin{array}{l}\text { Acroperus harpae Alona } \\
\text { guttata } \\
\text { Alona affinis }\end{array}$ & $\begin{array}{l}\text { Alona affinis } \\
\text { Chydorus sphaericus } \\
\text { Eurycercus lamellatus }\end{array}$ & $\begin{array}{l}\text { Alona guttata } \\
\text { Camptocercus } \\
\text { rectirostris Eurycercus } \\
\text { lamellatus }\end{array}$ & Eurycercus lamellatus \\
\hline & E1 & $\begin{array}{l}\text { Camptocercus } \\
\text { rectirostris Acroperus } \\
\text { harpae }\end{array}$ & $\begin{array}{l}\text { Alona quadrangularis } \\
\text { Bosmina longirostris }\end{array}$ & - & $\begin{array}{l}\text { Eurycercus lamellatus } \\
\text { Camptocercus } \\
\text { rectirostris } \\
\text { Chydorus sphaericus }\end{array}$ & - \\
\hline \multicolumn{2}{|c|}{$\begin{array}{c}\text { WARTA } \\
\text { GLACIATION }\end{array}$} & $\begin{array}{l}\text { Alona affinis } \\
\text { Alona guttata } \\
\text { Chydorus sphaericus }\end{array}$ & - & - & $\begin{array}{l}\text { Alona affinis } \\
\text { Alona quadrangularis }\end{array}$ & - \\
\hline
\end{tabular}

dinaria, Monospilus dispar, Pleuroxus uncinatus, and Sida cristallina, characterized by wide thermal and edaphic tolerance.

The development of lakes in the light of climate changes during the Eemian Interglacial

Lakes provide a specific life environment. Water acts as a buffer for environmental factors, increasing the stability and predictability of conditions (Lampert and Sommer 2001). Being contained systems, lakes prevent the "escape" of organisms in the event of unfa- vourable conditions. Lakes are short-lived formations in the geologic time scale (Rybak 2001). They undergo gradual evolution, usually ending in disappearance. Due to various biotic and abiotic factors, morphometric parameters and origins of the lakes, lakes formed at the same time within a specific area are at different stages of their development (Więckowski 1966). Reconstruction of the ecological and biological history of the lakes is possible as sequential stages are recorded in lacustrine and peat sediments (Tobolski 2000). 


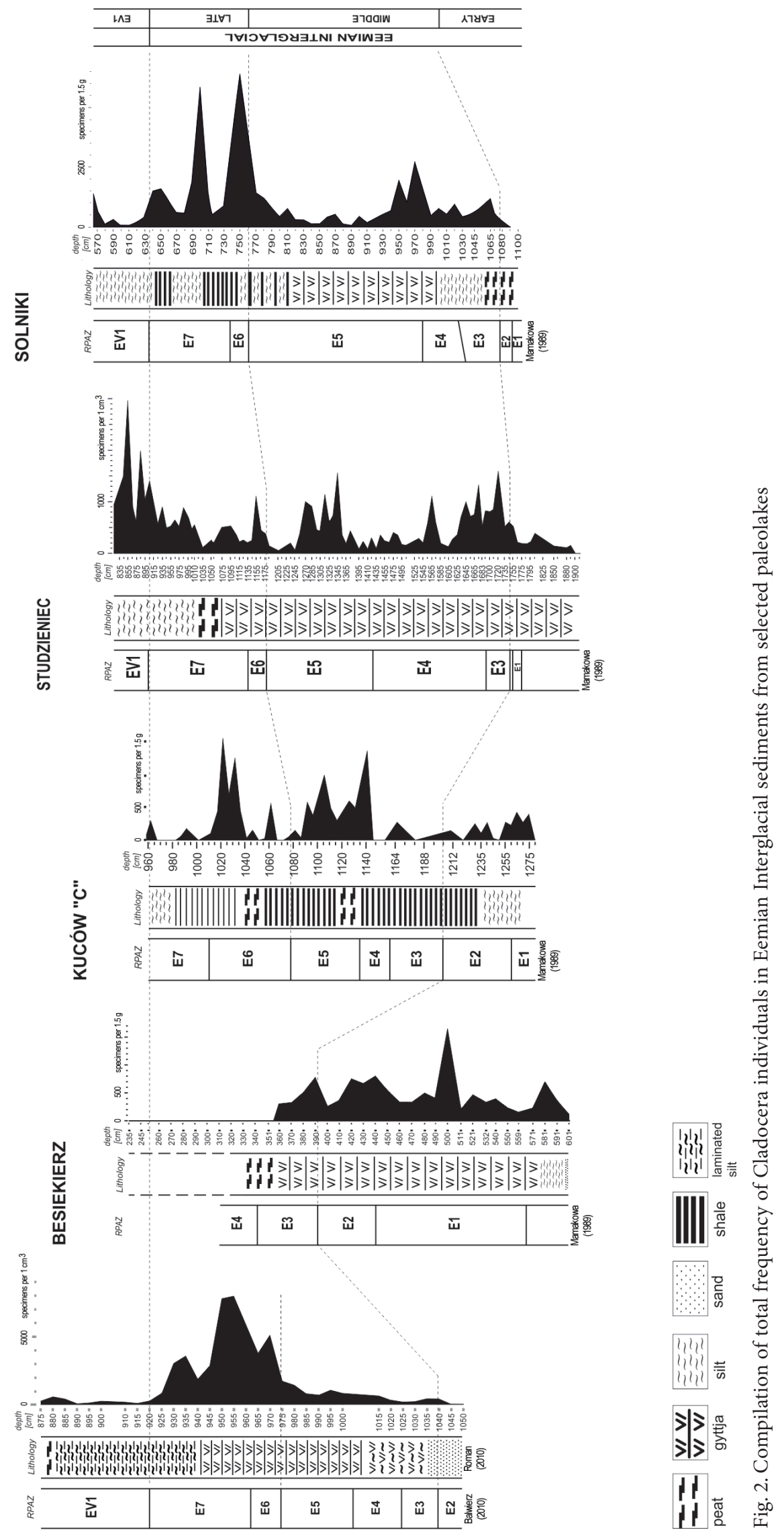


Late Warta Glaciation / Early Eemian Interglacial (RPAZ: E1 - E2)

Initially, the lake water temperatures were low. Lakes were inhabited mainly by pioneering fauna resistant to low temperatures, low clarity of water and low content of organic matter at the oligotrophic level. Species representing the initial stages of lake development occurring at the end of the Warta Glaciation and at the early Eemian Interglacial included Chydorus sphaericus, Eurycercus lamellatus, Alona affinis, Alona guttata, and Alona quadrangularis. First to emerge were Lakes Besiekierz and Studzieniec (late Warta glaciation); the succession of Cladocera species into Lakes Kuców IIc and Solniki followed at the beginning of the Eemian Interglacial, with Lake Kubłowo being the last to develop. As water temperature gradually increased, the lakes were inhabited by a more thermophilic species of Camptocercus rectirostris to emerge first within Lakes Besiekierz and Studzieniec. As these lakes were also the first to emerge, the presence of this species might be due not only to the improvement in thermal conditions, but also to the growth of macrophytes providing the dwelling environment for C. rectiorostris. As the water level also increased, the group of dominant species was enriched by pelagic zone species due to the somewhat larger precipitation at the early Eemian Interglacial (Cheddadi et al. 1998). The results of Cladocera analyses from the early Eemian Interglacial period demonstrate short-term episodes of climate warming during this relatively cold period, leading to an increase in Cladocera frequency (Fig. 2), being maintained at a low level in the initial period of lake development.

\section{Middle Eemian Interglacial (RPAZ: E3 - E5)}

Cladocera species composition from this period suggests more favourable conditions for zooplankton growth, probably due to a significant rise in temperatures. During the middle Eemian Interglacial period in central Europe, the air temperatures during the warmest month of the year reached the highest interglacial value, with precipitation at levels not higher than $700 \mathrm{~mm}$ (Zagwijn 1983). The improvement in thermal conditions led to an increase in the frequency of specimens and diversity of species. Species characterized by higher thermal requirements were present within all study reservoirs. The period correlated with pollen zone E3 was associated with an increase in the frequency of Cladocera specimens within Lake Studzieniec, while a similar increase was demonstrated for the remaining Lakes Kuców IIc, and Solniki within the period correlated with pollen zone E4 (Fig. 2). As the temperature increased, so did the fecundity of the lake environment, reaching the mesotrophic state, or even eutrophic state at the end of the middle Eemian Interglacial within the largest lakes, Solniki, Studzieniec, and Kubłowo, as evidenced by the presence of indicator species (such as Pleuroxus uncinatus). The increase in water temperature, initially favouring the development of lacustrine ecosystems, led to increased vaporization and thus to the lowering of water levels. This was most pronounced in case of Lake Solniki. The most rapid significant drop in water level occurred within Lakes Kuców IIc and Besiekierz, where the effect of climate conditions associated with the end of pollen zone E3 resulted in excess drying of sediments and deposition of peats. In the case of Lake Besiekierz, the process led to the lake being transformed into a peat bog.

According to Zagwijn (1996), pollen zone E4 was associated with a general significant drop in air temperatures. This has also been observed in the studied reservoirs, being particularly evident in Lake Studzieniec, where the frequency of specimens of all Cladocera species was reduced (Fig. 2).

Also, according to Zagwijn (1996), pollen zone E5 was associated with a drop in July temperatures as well as in an increase in the temperatures of the coldest month of the year by about $3^{\circ} \mathrm{C}$. At the time, hornbeam woods were predominant over the entire territory of present-day Poland, with fir and spruce also occurring. The vegetation period became shorter, accompanied by significant cooling and increased humidity of the climate. This climate had a favourable effect on the existence of lakes within central Poland as reflected by a significant development in Cladocera species. This was particularly evident in the sediments of Lakes Kuców IIc and Studzieniec, wherein conditions favouring the growth of fauna occurred within the period correlated with pollen zone E5. Lake Solniki, located to the east, witnessed a drop in the water level within the period of pollen zone E5 (Kupryjanowicz 2008), and thus a deterioration in the conditions for zooplankton growth. However, also in the case of this lake, an unquestionable increase in the frequency of Cladocera specimens within the deposits can be observed at the late E5 phase.

\section{Late Eemian Interglacial (RPAZ: E6, E7)}

The Late Eemian Interglacial was the next stage of the development of water reservoirs associated with a considerable improvement in Cladocera habitat 
conditions. The final stage Eemian Interglacial was associated with a significant drop in temperatures; however, precipitation was maintained at a relatively high level of more than $800 \mathrm{~mm}$ of average rainfall (Zagwijn 1996). The temperature drop had no adverse effect on the condition of Cladocera species inhabiting the lake. Higher precipitation due to the influence of the oceanic climate (Zagwijn 1996) led to an elevation of water levels and thus to an increase in the frequency of most Cladocera species within Lakes Solniki, Kuców IIc, Studzieniec, and Kubłowo. The frequency of Cladocera species reached the top level throughout the history of the lakes (E6/E7). The period correlated with the pollen zone E7 was associated with periods of rapid drops in the frequency of species, possibly suggesting mid-interglacial cooling (Fig. 2).

Lake Kuców IIc was the first to undergo terrestrialization at the end of the late Eemian period. The frequency of Cladocera species in two other lakes, Solniki and Kubłowo, was reduced virtually to a minimum level. Thermophilic Cladocera species survived within all studied lakes until the end of the Eemian Interglacial. During the first pollen zone of the Vistulian Glaciation, the dominant species within both the remaining lakes, Solniki and Kubłowo, was the eurytopic species of Chydorus sphaericus, characterized by broad tolerance to water temperatures but favouring more fecund reservoirs (Table 1).

As significant climate changes occurred at the end of the Eemian Interglacial, the lakes that had existed for about 11 thousand years (Müller 1974) were transformed into peat bogs; however, some of these lakes, for example Lakes Studzieniec and Kubłowo, were retained despite the deteriorating conditions associated with the approaching glaciation due to their specific properties including the basin profile, depth and favourable local conditions.

\section{Conclusions}

The Eemian lakes selected for this study were formed at the end of the Warta Glaciation in tunnel and kettle holes. Sediments accumulated within the basins consisted of sands, silts, peats and organic shales; the reservoirs were relatively shallow, characterized by well-developed littoral zones and lack of proper pelagic zones.

$\Rightarrow$ A continuous record of environmental changes starting from the late Warta Glaciation throughout the entire Eemian Interglacial and until the early
Vistulian Glaciation has been preserved in lake sediments.

$\Rightarrow$ Similar development stages reflected in changes in Cladocera composition were identified in all reservoirs starting from the initial period. The lake development patterns were associated with morphometric parameters of the lakes as well as with local and regional climate conditions.

$\Rightarrow$ The lake development stages were as follows:

- gradual climate warming, zooplankton growth, emergence of thermophilic Cladocera species favouring oligotrophic reservoirs;

- deterioration of conditions, possibly a temperature drop and a reduction in water level, retreat of most Cladocera species;

- improvement of climate condition, return of thermophilic species favouring higher trophic states, high diversity of species;

- basin overgrowth, possible eutrophic or dystrophic conditions, accumulation of peats.

$\Rightarrow$ Cladocera species determined within the studied paleolakes correspond to the present-day species inhabiting the area of Poland and Europe, while the changes in species composition correspond to present-day geographical distribution of Cladocera species. The identified subfossils were not significantly different from the remains found in presentday lakes.

$\Rightarrow$ At the sequential stages of lake development (correlated with pollen zones), dominant species were characterized by low habitat requirements and high resistance to environmental stress.

$\Rightarrow$ The trophic state of the reservoirs was at the oligo/ mesotrophic level, with the exception of the largest lakes, Solniki, Studzieniec, and Kubłowo, where an increase in species frequency suggestive of lake eutrophization was observed at the stage of the fullest fauna growth.

$\Rightarrow$ Each of the studied paleolakes followed a slightly different development pattern due to different local conditions as well as to local climate changes in their immediate environment.

\section{Acknowledgments}

The research project was supported by the Foundation for Polish Science, Bridge Program 2012 - project: "Reconstruction of the development of lake environment in the Eemian Interglacial based on subfossil Cladocera (Crustacea) analysis". 


\section{References}

Alhonen P., 1986, Holocene lacustrine microfossils and environmental changes, Bull. Geol. Soc. Finland. 58: 57-69.

Balwierz Z., 1998, Interglacjał eemski i wczesny Vistulian w Kucowie (Eemian interglacial and early Vistulian at Kuców) [Abstract], Mat. 51 Zjazdu PTB “Botanika Polska u progu XXI wieku”, 15-19 września, Gdańsk: 18 (in Polish).

Cheddadi R., Mamakowa K., Guiot J., de Beaulieu J.L., Reille M., Andrieu V., Granoszewski W., Peyron O., 1998, Was the climate of the Eemian stable? A quantitative climate reconstruction from seven European pollen records, $\mathrm{Pa}$ leogeogr. Paleoclimat. Paleoecol. 143:73-85.

Coccrell T.D.A., 1922, A Fossil buttercup, Nature 109(2724): 42-43.

Dickinson K.A., 1959, The Ostracoda and Cladocera of the Humboldt Formation in northeastern Nevada [Thesis] Univ. of Minnesota, Minneapolis, pp. 47.

Erni A., Forcart L., Härri H., 1943, Fundstellen pleistocaener Fossilien in der "Hochterrasse" von Zell (Kt. Luzern) und in der Moräne der grössten Eiszeit von Auswil bei Rohrbach (Kt. Bern), Eclogae Geol. Helv. 36(1): 85-124 (in German).

Flössner D., 1972, Krebstiere, Crustacea. Kiemen- und Blattfußer, Branchiopoda. Fischläuse, Branchiura, Die Tierwelt Deutschlands 60: 1-501 (in German).

Flössner D., 2000, Die Haplopoda und Cladocera (ohne bosminidae) Mitteleuropas (Haplopoda and Cladocera (without Bosminidae) in Central Europe), Backhuys Publisher, Leiden, pp. 425 (in German).

Frey D.G., 1958, The late-glacial cladoceran fauna of a small lake, Arch. Hydrobiol. 54: 200-275.

Frey D.G., 1962, Cladocera from the Eemian Interglacial of Denmark, J. Palaeontol. 36: 1133-1154.

Frey D.G., 1986, Cladocera analysis, [in:] Berglund B.E. (ed.), Handbook of Holocene Paleoecology and Palaeohydrology, Wiley, Chichester: 667-692.

Goulden C.E., 1964, The history of the cladoceran fauna of Esthwaite Water (England) and its limnological significance, Arch. Hydrobiol. 60: 1-53.

Hann B.J., Karrow P.F., 1984, Pleistocene paleoecology of the Don and Scarborough Formations, Toronto, Canada, based on cladocera microfossils at the Don Valley Brickyard, Boreas 13: 377-391.

Hann B.J., Karrow P.F., 1993, Comparative analysis of cladoceran microfossils in the Don and Scarborough Formations, Toronto, Canada, J. Paleolimnol. 9: 223-241.

Hofmann W., 1986, Developmental history of the Grosser Plöner See and the Schöhsee (north Germany): cladoceran analysis, with special reference to eutrophication, Arch. Hydrobiol. /Suppl. 74: 259-287.

Hofmann W., 2000, Response of the chydorid faunas to rapid climatic changes in four alpine lakes at different altitudes, Paleogeogr. Paleoclimat. Paleoecol. 159(3-4): 281-292.
Janczyk-Kopikowa Z., 1991, Palynostratigraphy of the Pleistocene in Poland and the problem of the age of deposits from Besiekierz (Central Poland), Ann. UMCS Sec. B 64(6): 111-128.

Jessen K., Milthers V., 1928, Stratigraphical and paleontological studies of interglacial fresh-water deposits in Jutland and north-west Germany, Danm. Geol. Unders. II Raekke 48: 1-380.

Kadota S., 1975, A quantitative study of the microfossils in a 200-meter-long core sample from lake Biwa, Paleolimnol. Lake Biwa Jpn. Pleistocene 3: 354-367.

Kaspar, F. Kühl N., Cubasch U., Litt T., 2005, A model-data comparison of European temperatures in the Eemian interglacial, Geophys. Res. Lett. 32: L11703.

van Kolfschoten Th., 2000, The Eemian mammal fauna of central Europe, Neth. J. Geosci. 79(2-3): 269-281.

Korhola A., 1990, Paleolimnology and hydroseral development of the Katasuo Bog, Southern Finland, with special reference to the Cladocera, Ann. Acad. Sci. Fenn. 155: 5-40.

Korhola A., Rautio M., 2001, Cladocera and other branchiopod crustaceans, [in:] Smol J.P. Birks H.J.B., Last W.M. (eds), Tracking Environmental Change Using Lake Sediments. Vol. 4: Zoological Indicators, Kluwer Academic Publishers, Dordrecht: 5-41.

Krupiński K.M., 2005, The investigation of the Younger Pleistocene lacustrine sediments of the Płock Upland, Pr. PIG 184:1-58.

Kupryjanowicz M., 2008, Vegetation and climate of the Eemian and Early Vistulian lakeland in northern Podlasie, Acta Palaeobot. 48(1): 3-130.

Lampert W., Sommer U., 2001, Ekologia wód śródlądowych (Limnoecology), Wydaw. Nauk. PWN, Warszawa, pp. 390 (in Polish).

Lindner L. (ed.), 1992, Czawartorzęd. Osady, metody badań, stratygrafia (Quaternary. Sediments, methods, stratigraphy), Wydaw. PAE., Warszawa, pp. 683 (in Polish).

MacGinitie H.D., 1949, Ruppia balls [letter in the "Correspondence" section], Scient. Monthly 68: 2-74.

MacGinitie H.D., 1953, Fossil plants of the Florissant beds, Colorado, Carn. Inst. Wash. Publ. 599: 1-198.

Mamakowa K., 1989, Late Middle Polish Glaciation, Eemian and Early Vistulian vegetation at Imbramowice near Wrocław and the pollen stratigraphy of this part of the Pleistocene in Poland, Acta Palaeobot. 29: 11-176.

Mirosław-Grabowska J., Niska M., 2005, Isotopic and Cladocera records of climate changes of Early Eemian at Besiekierz (Central Poland), Geol. Quart. 49(1): 67-74.

Mirosław-Grabowska J., Niska M., 2007, Reconstruction of environmental conditions of Eemian palaeolake at Studzieniec (Central Poland) on the basis of stable isotope and Cladocera analyses, Quaternary Int. 162-163: 195-204.

Müller G., 1974, Pollenanalytische untersuchungen und jahresschichtenzählungen an der eemzeitlichen kieselgur von Bispingen/Luhe, Geol. Jahrb. A21: 149-169 (in German). 
Nevalainen L., Luoto T.P., Kultti S., Sarmaja-Korjonen K., 2013, Spatio-temporal distribution of sedimentary Cladocera (Crustacea: Branchiopoda) in relation to climate, J. Biogeogr. 40: 1548-1559.

Niska M., 2008, Interpretacja zmian środowiska jeziornego w interglacjale eemskim na podstawie analizy kopalnych Cladocera (Interpretation of lacustrine environment changes during the Eemian interglacial based on the Cladocera subfossil analysis) [Thesis], Akademia Pomorska w Słupsku, Słupsk, p. 127.

Niska M., 2012, Fossil Cladocera remains in the Eemian sediments - preservation, frequency and dominant species, Studia Quatern. 29: 31-43.

Niska M., Roman M., 2014, A reconstruction of development of Paleolake Kubłowo in the Eemian Interglacial based on the Cladocera subfossil analysis - preliminary results, Studia Quatern. 31(1): 31-38.

Pawłowski D., 2002, Eemskie subfosylne szczątki Cladocera ze Sławoszewka: obszar koniński (Eemian Cladocera subfossil remains from Sławoszewko: Konin region) [Abstract], Streszcz. Referatów Poznańskiego Oddziału Polskiego Towarzystwa Geologicznego 11: 70-79 (in Polish).

Poulsen E., 1928, Faunistische und biologische Unterschungen über die Cladocerafauna von Danmark, Vidensk. Medd. Dan. Naturhist. Foren. 86: 203-242 (in German).

Roman M., Balwierz Z., 2010, Eemian and Vistulian pollen sequence at Kubłowo (Central Poland): implications for the limit of the Last Glacial Maximum, Geol. Quart. 54(1): 55-68.

Rybak J.I., 2001, Przewodnik do rozpoznawania niektórych bezkręgowych zwierząt słodkowodnych (A guidebook to the identification of some freshwater invertebrates), Wydaw. Nauk. PWN, Warszawa, pp.75 (in Polish).

Sarmaja-Korjonen K., 2002, Multi-proxy data from Kaksoislammi Lake in Finland: dramatic changes in the late Holocene cladoceran assemblages, J. Paleolimnol. 28(3): 287-296.
Shackleton N.J., Opdyke N.D., 1976, Oxygen-isotope and paleomagnetic stratigraphy of Pacific core V28-239 late Pliocene to latest Pleistocene, Geol. Soc. Am. Mem. 145: 449-464.

Szeroczyńska K., 1985, Cladocera jako wskaźnik ekologiczny w późnoczwartorzędowych osadach jeziornych Polski Północnej (Cladocera as ecologic indicator in late Quaternary lacustrine sediments in Northern Poland), Acta Palaeontol. Pol. 30(1-2): 3-69 (in Polish, English summary).

Szeroczyńska K., Sarmaja-Korjonen K., 2007, Atlas of Subfossil Cladocera from Central and Northern Europe, Wydaw. Tow. Przyjaciół Dolnej Wisły, Świecie, pp. 84.

Tobolski K., 1991, Biostratygrafia i paleoekologia interglacjału eemskiego i zlodowacenia Wisły rejonu konińskiego (Biostratigraphy and paleoecology of the Eemian interglacial and the Vistulian glaciation of the Konin region), [in:] Stankowski W. (ed.), Przemiany środowiska geograficznego obszaru Konin-Turek. Wyniki realizacji programu RR. II. 14 w okresie 19861990 (Changes in the geographical environment in the Konin-Turek region. Results of the PR.II.14 Program during the years 1986-1990), Inst. Badań Czwart. UAM, Poznań: 45-87 (in Polish).

Tobolski K., 2000, Przewodnik do oznaczania torfów i osadów jeziornych (A guide to the determination of peat and lacustrine sediments), Wydaw. Nauk. PWN, Warszawa, pp. 508.

Tsukada M., 1972, The history of lake Nojiri, Japan. Trans. Conn. Acad. Art. Sci. 44: 339-365.

Więckowski K., 1966, Osady denne jeziora Mikołajskiego (Bottom deposits of Lake Mikołajki), Pr. Geogr. 57: 1-112 (in Polish, Russian and English summary).

Zagwijn W.H., 1996, An analysis of eemian climate in western and Central Europe, Quatern. Sci. Rev. 15: 451-469. 
